\title{
Rhexoxylon brunoi Artabe, Brea et Zamuner, sp. nov., a new Triassic corystosperm from the Paramillo de Uspallata, Mendoza, Argentina
}

\author{
A.E. Artabe*, M. Brea, A.B. Zamuner \\ CONICET and Paleobotanical Department, School of Natural Sciences and Museum of La Plata, U.N.L.P., Paseo del Bosque s/n, 1900 \\ La Plata, Argentina
}

Received 23 January 1996; revised version received 7 September 1998; accepted 14 September 1998

\begin{abstract}
A new species of Rhexoxylon from the Upper Triassic of Argentina is described. The material was collected at El Paramillo de Uspallata area and comes from Los Colorados Formation. There is a big buried specimen and scattered material which is preserved by silicification, corresponding to an adult eccentric, oval trunk, whose diameter is $71 \times 58$ $\mathrm{cm}$. Three zones can be distinguished: pith, vascular (with perimedullar bundles and centrifugal wedges of secondary xylem) and cork layer. Rhexoxylon brunoi Artabe, Brea et Zamuner, sp. nov. has a heterogeneous pith with parenchyma cells and idioblasts. Perimedullar bundles make up two cycles; the first one is complete constituted by double collateral bundles, facing each other, with secondary growth. The second one is incomplete, showing just the centripetal xylem sector. Peripheral centrifugal secondary xylem wedges show extensive development, reaching up to $38 \mathrm{~cm}$ of thickness. The tracheids of secondary xylem have opposite uni- to biseriate bordered radial pitting, and crossfields with one or two simple, slanted lenticular pits. Outside of the xylem a cork layer of about $2 \mathrm{~cm}$ persists conforming a longitudinally and transversely fractured rhytidome-like zone. Rhexoxylon brunoi shows a morpho-structural pattern determined by high activity of normal cambium, moderate activity of supernumerary cambium and scarce activity of remanent cambium. (C) 1999 Elsevier Science B.V. All rights reserved.
\end{abstract}

Keywords: paleobotany; systematic; corystosperms; Rhexoxylon; Upper Triassic; Argentina

\section{Introduction}

In the province of Mendoza, the Cuyana Basin (sensu Kokogian and Mancilla, 1989) includes six main subbasins of Triassic continental sediments, among which is that of Las Peñas, approximately $2000 \mathrm{~m}$ thick. To the west of the latter, in the out-

$\overline{* \text { Corresponding author. Fax: }+54-21-257527 .}$ crop area identified as Villavicencio-Paramillo de Uspallata, the Uspallata Group with five formations (Río Mendoza, Las Cabras, Potrerillos, Cacheuta and Río Blanco) was recognized by Stipanicic (1979) (Fig. 1). At El Paramillo de Uspallata, in the zone comprised by the San Bartolo Range and Los Colorados Hill, the sedimentary sequence includes four units: the Paramillo, Agua de la Zorra, Portezuelo Bayo and Los Colorados formations (Harrington, 1971), which are correlatable with the middle and 


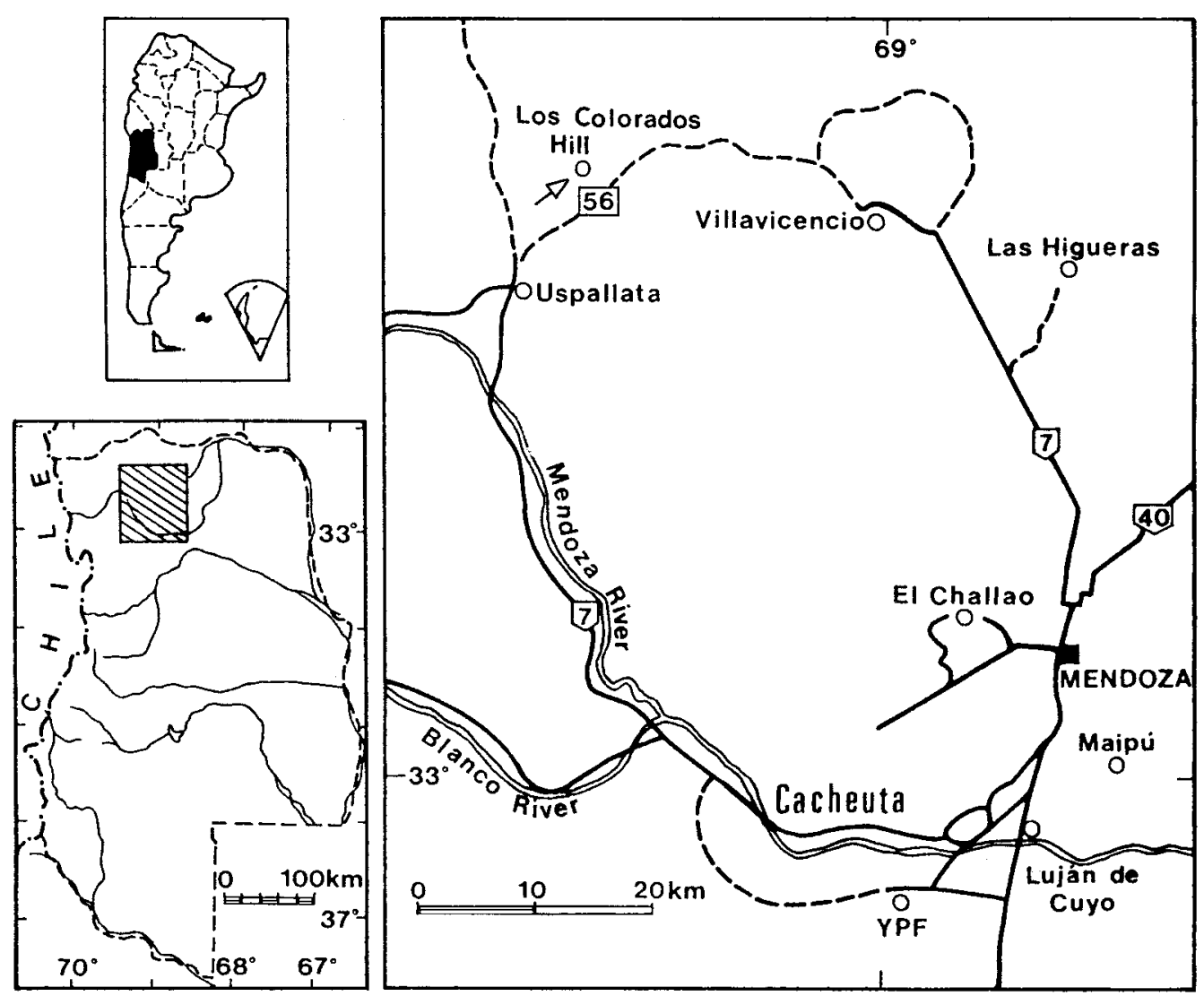

Fig. 1. Geographic location of the fossiliferous locality.

upper parts of the Uspallata Group (Fig. 2; Strelkov and Alvarez, 1984; Ramos, 1993).

The Paramillo de Uspallata area has been the object of several geological studies (Harrington, 1971; Strelkov and Alvarez, 1984; Massabie, 1985; Massabie et al., 1985; Kokogian and Mancilla, 1989; Linares and Gonzáles, 1990; Ramos and Kay, 1991; Ramos, 1993; Kokogian et al., 1993). Little is known as to its paleontological content (Conwentz, 1885; Stappenbeck, 1910; Kurtz, 1921; Du Toit, 1927; Groeber, 1939; Windhausen, 1941; Harrington, 1971; Stipanicic et al., 1996) even though Darwin (1846) noted the existence of a petrified forest, fossilized in situ (assigned to Araucarites).

Because of these reasons, and within the $\mathrm{CON}$ ICET (National Research Council of Argentina) Proyect PID 330/92, the outcrops of the El Paramillo, Agua de la Zorra and Los Colorados formations, in the Agua de la Zorra zone, were revised. The paleofloristical content is currently being studied and is the object of the doctoral thesis of one of the authors (Brea, 1995). On the Los Colorados Formation (sensu Harrington, 1971), material assignable to a new species of Rhexoxylon Bancroft emend Archangelsky et Brett, 1961 (Artabe et al., 1994) has been found. The aim of this work is the description of this taxon and the comparison with previously described species.

\section{Materials and methods}

The studied material comes from the Los Colorados Formation (sensu Harrington, 1971) cropping out in El Paramillo de Uspallata zone, on Los Colorados Hill, situated at $32^{\circ} \mathrm{S}, 68^{\circ} \mathrm{W}$, at approximately 


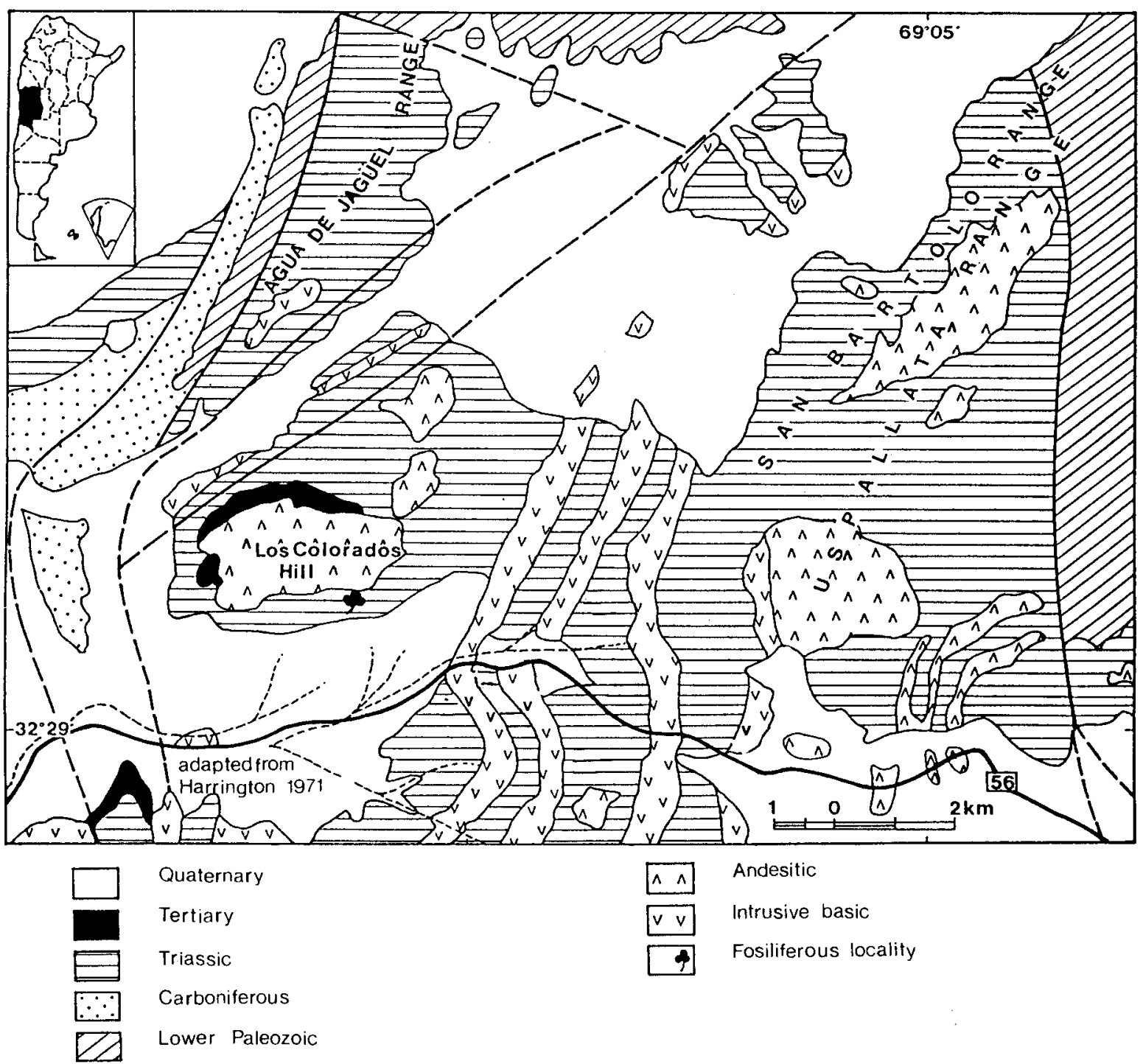

Fig. 2. Geological map of the region showing Triassic units of El Paramillo de Uspallata (modified from Harrington, 1971).

$15 \mathrm{~km}$ from the city of Uspallata, Mendoza, Argentina (Figs. 1 and 2). It was collected by two of the authors (A.A. and M.B.) during a fieldwork in 1994. The specimens were found in deep red sandstone, with medium grain size, compact and solid, stratified in thick beds.

Specimens are silicified trunks which are deposited in the Paleobotanical collection of the La Plata Museum, under the acronym LPPB. The samples correspond to scattered material and to a large, partially buried specimen, whose exposed part is approximately $3 \mathrm{~m}$ long. The dimensions of the buried trunk made transportation impossible, thus hand drawing of a complete transversal section (Fig. 4) was made on the specimen, in the field. Samples of each of the zones recognized in the stem were collected. Surface polishing and thin sections were done using traditional techniques. The material was studied with light microscopy (Iroscope YZ6 and Wild M11) and camera lucida (Wild M5). 


\section{Systematics}

Class GYMNOSPERMOPSIDA

Order PTERIDOSPERMALES

Family CORYSTOSPERMACEAE Thomas, 1933

Genus Rhexoxylon Bancroft emend. Archangelsky et Brett, 1961

Type: Rhexoxylon africanum Bancroft, 1913 emend. Walton, 1923

Rhexoxylon brunoi Artabe, Brea et Zamuner, sp. nov. (Plates I and II; Figs. 3-6)

Holotype: LPPB 12960-12974, LPPBpm 1556-1561. Paratypes: LPPB 12975-12984.

Repository: Paleobotany Department, La Plata $\mathrm{Mu}-$ seum, U.N.L.P. Argentina.

Stratigraphic and geographic origin: Los Colorados Formation (Upper Triassic), Villavicencio-Uspallata Subbasin, Los Colorados hill, Mendoza province.

Etymology: This species is dedicated to the late Dr. Bruno Petriella, an outstanding Argentinian paleobotanist, who made important advances in the knowledge of the Corystospermaceae family.

Diagnosis: Mature columnar stem, up to $71 \mathrm{~cm}$ in diameter, differentiated into pith, vascular cylinder and cork layer. Small oval, heterogeneous pith with parenchyma cells and idioblasts. The vascular cylinder comprises two cycles of perimedullar bundles and a peripheral zone of centrifugal secondary xylem wedges. The first cycle of perimedullar bundles made up of 16 collateral double bundles, facing each other, constituted of centripetal-centrifugal secondary xylem, oval-rounded, contiguous, separated by very thin medullary rays; second cycle (incomplete) showing only centripetal secondary xylem. Zone of centrifugal wood wedges $38 \mathrm{~cm}$ thick; wedges of xylem related to perimedullar bundles, each one separated from the contiguous one by narrow parenchymatous rays up to $1 \mathrm{~cm}$ wide; having fan-like form; radial and cross fragmentation produced by dilatation parenchyma. Radial intervascular bordered pitting contiguous uniseriate, with occasional opposite biseriate, and crossfields show one or two simple, slanted and lenticular pits. Tracheids show simple or double spiral tertiary thickenings. Cork layer of $2 \mathrm{~cm}$ persists conforming a longitudinally and transversely fractured rhytidome-like zone.
Description: The trunk is eccentric, of oval shape with a major diameter of $71 \mathrm{~cm}$ and a minor one of $58 \mathrm{~cm}$. It is differentiated into pith, vascular zone and cork layer (Plate I, 1). The pith is $2.4 \times 1.7$ $\mathrm{cm}$; it is oval and heterogeneous (Plate I, 2), with spheroidal parenchymatous cells of $105 \times 110 \mu \mathrm{m}$ and polygonal isodiametric idioblasts, with dark contents of $115 \times 110 \mu \mathrm{m}$. The vascular zone presents two rings of perimedullar bundles $2.1 \mathrm{~cm}$ thick (Plate I, 2; Fig. 3) above described. The peripheral sector of centrifugal wedges up to $38 \mathrm{~cm}$ thick (Plate II, 1, 2 ; Fig. 4) develops around the second ring of perimedullar bundles and is related with it. Each wedge is separated from the contiguous one by parenchymatous rays up to $1 \mathrm{~cm}$ wide; they are fan-like and fragment at different levels by means of parenchymatous rays of different radial length. The tangential dilatation parenchyma, which frequently fragments secondary xylem wedges, measures between 0.01 and $0.1 \mathrm{~cm}$, exceptionally up to $0.3 \mathrm{~cm}$. Tracheids measure $60 \times 74.7 \mu \mathrm{m}$. The bordered pits are approximately $30 \mu \mathrm{m}$ in diameter and are contiguous uniseriate or partially opposite biseriate (Fig. 5a). Crossfields present one or two simple, slanted lenticular pits $41.15 \times 17.14 \mu \mathrm{m}$ (Fig. $5 b$ ).

The cork layer is $2 \mathrm{~cm}$ thick with quadrangular or rectangular suberized cells $16 \mu \mathrm{m}$ wide $\times 23 \mu \mathrm{m}$ high; this tissue persists over the trunk conforming longitudinally and transversally fractured rhytidomelike zone (Plate II, 3, 4).

Discussion and comparisons: Rhexoxylon Bancroft, 1913 emend. Archangelsky et Brett, 1961 was created for permineralized specimens with a distinctive secondary xylem distribution. All the species assigned to these genus are characterized by a pith surrounded by a secondary vascular cylinder composed of two zones; the inner with one or more cycles of strands of secondary xylem that are either centripetal or both centripetal and centrifugal (perimedullar zone); and the outer with wedges of centrifugal secondary xylem separated by parenchy-

PLATE I

Rhexoxylon brunoi Artabe, Brea et Zamuner, sp. nov.

1. General aspect of trunk showing the pith and vascular zone.

2. Detail of the pith and the zone of perimedullar bundles. 


\section{PLATE I}
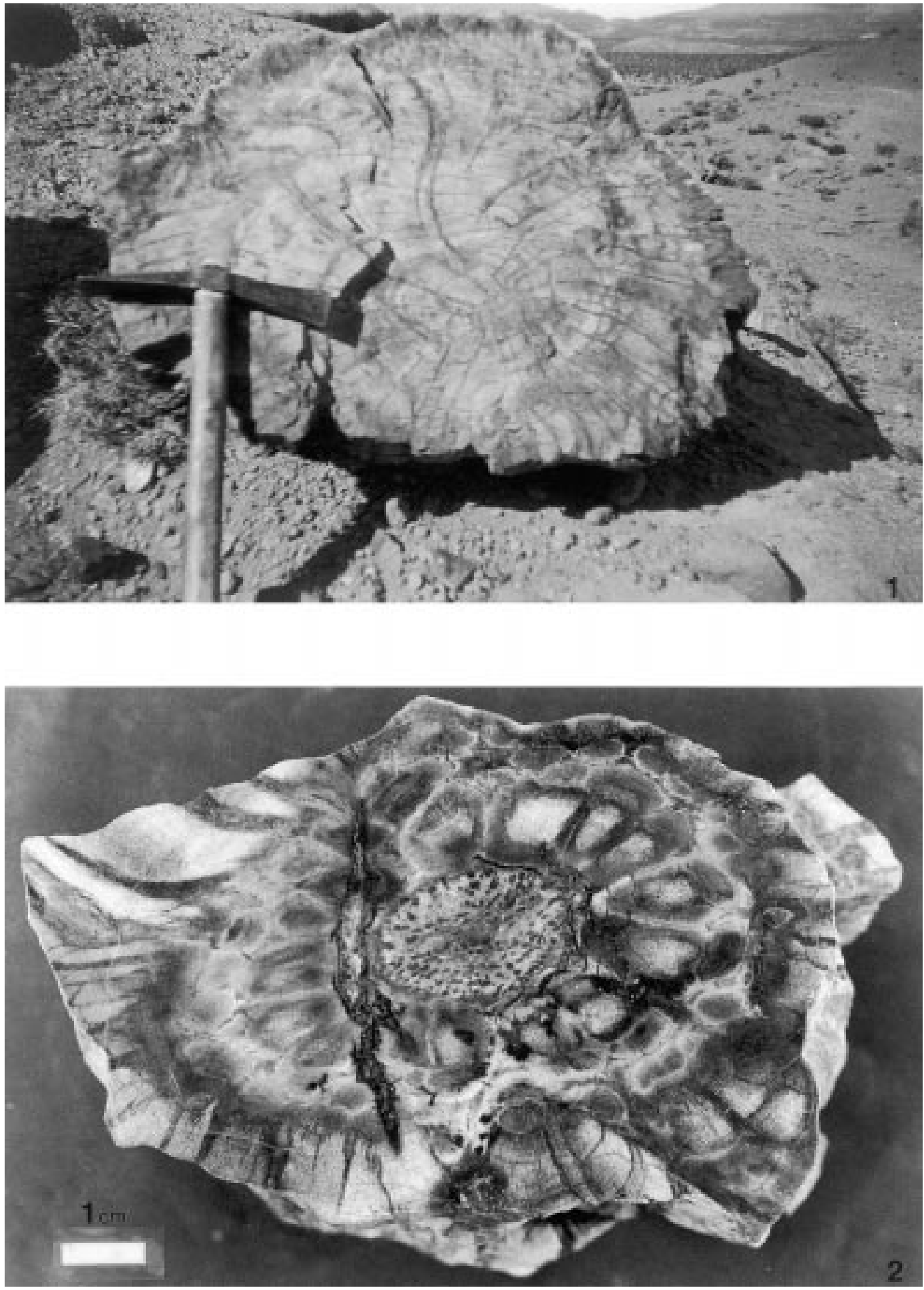

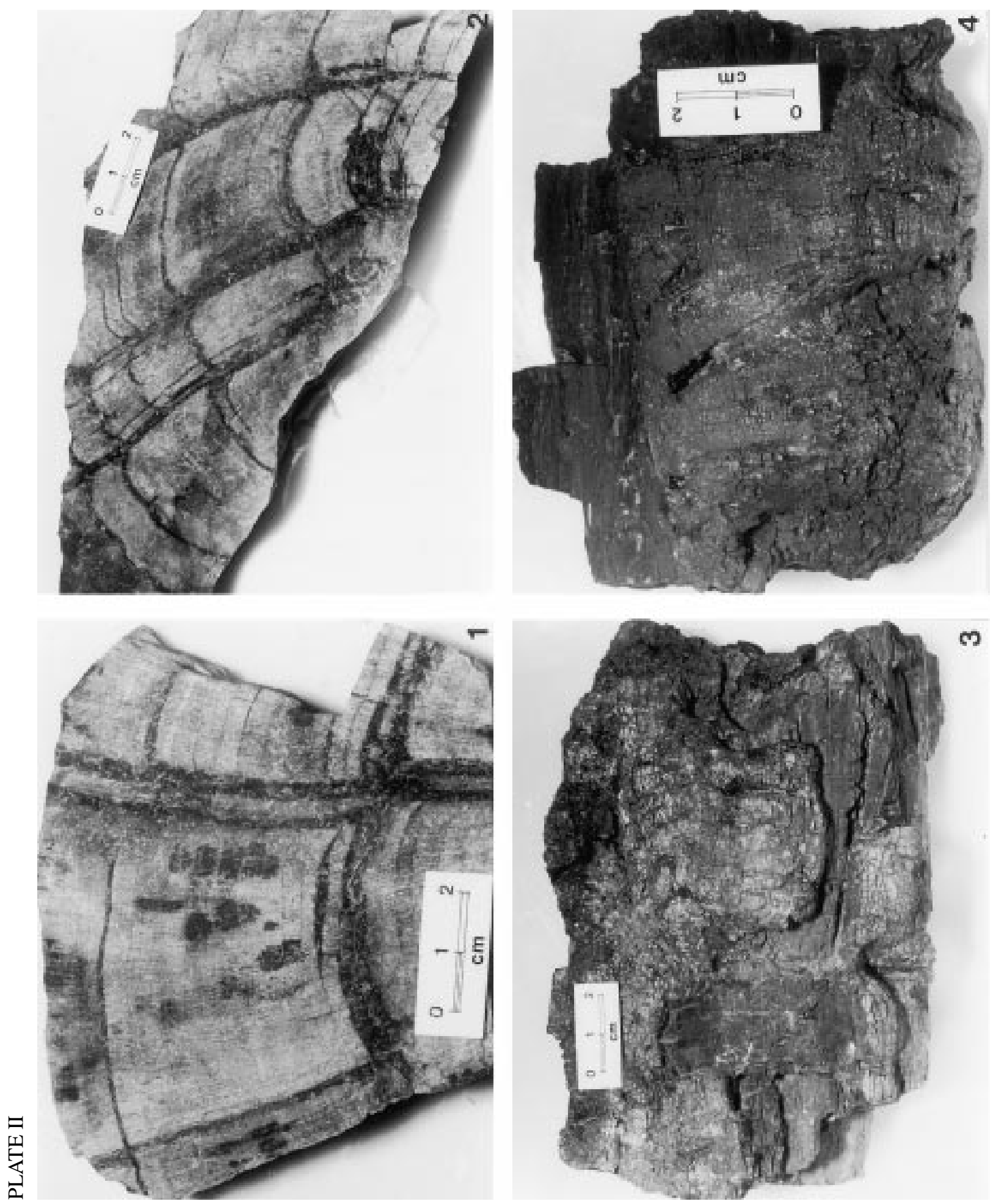


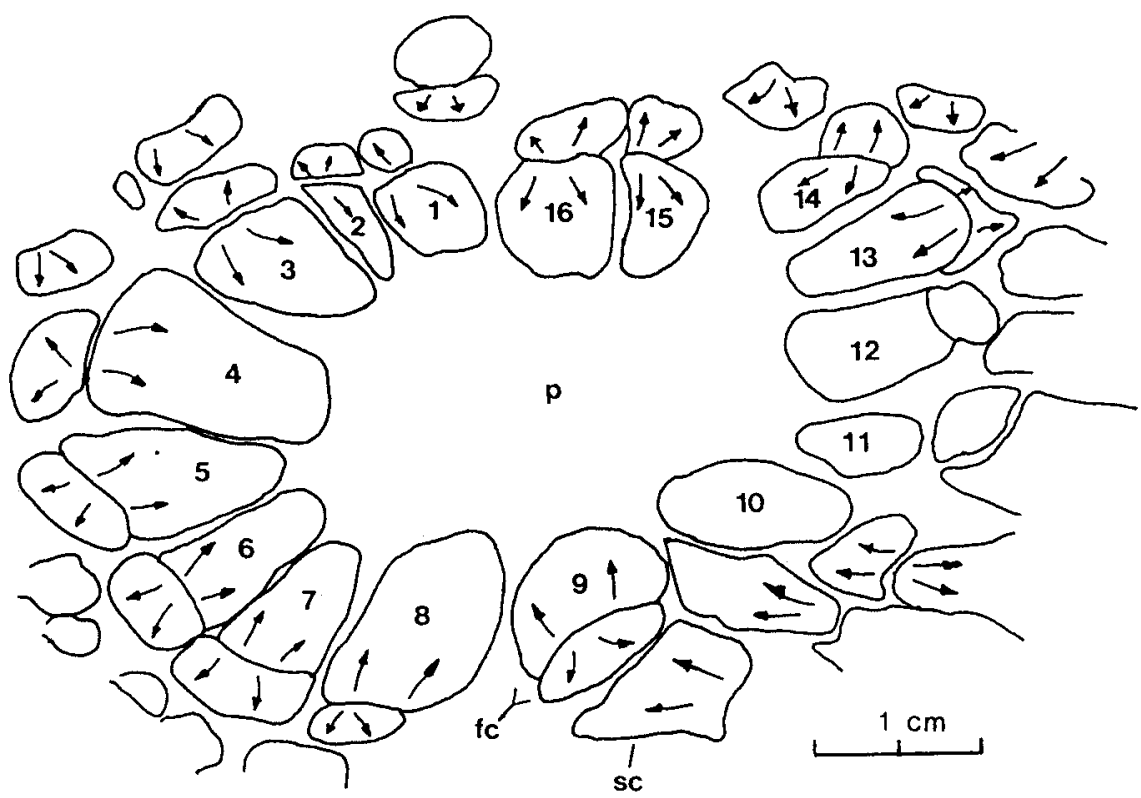

Fig. 3. Rhexoxylon brunoi Artabe, Brea et Zamuner, sp. nov. Diagram of the perimedullar zone and detail of cycles of vascular bundles. $p=$ pith; $f c=$ first cycle of perimedullar bundle made up 16 collateral double bundles, constituted of centripetal-centrifugal secondary xylem; $s c=$ second cycle (incomplete) showing only centripetal secondary xylem.

matous rays. The anatomy of Rhexoxylon has been interpreted as a consequence of an unusual secondary growth (Brett, 1968; Zamuner, 1992). A parenchymatic and xylematic proliferation within perimedullar zone and peripheral centrifugal xylem wedges triggers a mechanism of vascular fragmentation (remanent and supernumerary cambial activity; Zamuner, 1992). This has been called 'dilatation parenchyma' or 'adventitious parenchyma' because it dilates or separates the xylem (Walton, 1923; Obaton, 1960; Archangelsky and Brett, 1961; Bonnamain et al., 1963; Herbst and Lutz, 1988).

Up to now two species have been recognized from South Africa, $R$. africanum Bancroft emend. Walton, 1923 and R.tetrapteridoides Walton emend. Archangelsky et Brett, 1961, because R.waltonii Kräusel, 1956 was synonymized by Archangelsky and Brett (1961) with R.africanum. In South Amer-

\section{PLATE II}

Rhexoxylon brunoi Artabe, Brea et Zamuner, sp. nov. 1,2. Detail of centrifugal secondary xylem wedges.

3, 4. General aspect of cork layer. ica three species of this genus have been found. $R$. piatnitzkyi Archangelsky et Brett, 1961, described from the Ischigualasto Formation, province of San Juan, Argentina (Archangelsky and Brett, 1961; Archangelsky, 1968; Brett, 1968), R. brasiliensis found in the Caturrita Formation, Rio Grande do Sul, Brasil (Herbst and Lutz, 1988) and a new species preliminarily described from the Barreal Formation, province of San Juan, Argentina (Lutz and Herbst, 1992)

In Antarctica, Taylor (1992) described a portion of a stem as Rhexoxylon sp. because of the secondary wood in the form of wedges and the parenchymatous ground tissue.

Comparing histological characters of the pith, secondary xylem and cortex of the different species of the genus (Table 1), the pith shows sclerotic nests, secretory cavities and vascular strands in every taxon. $R$. brunoi is the only species with a parenchymatous pith with idioblasts. Secondary xylem in R.tetrapteridoides, R.africanum, R.piatnitzkyi and Rhexoxylon sp. (Taylor, 1992) consists of tracheids with uni- to biseriate alternate bordered pitting and crossfields with 1 to 4 simple pinoid pits. $R$. brunoi has uni or partially biseriate opposite bordered radial 


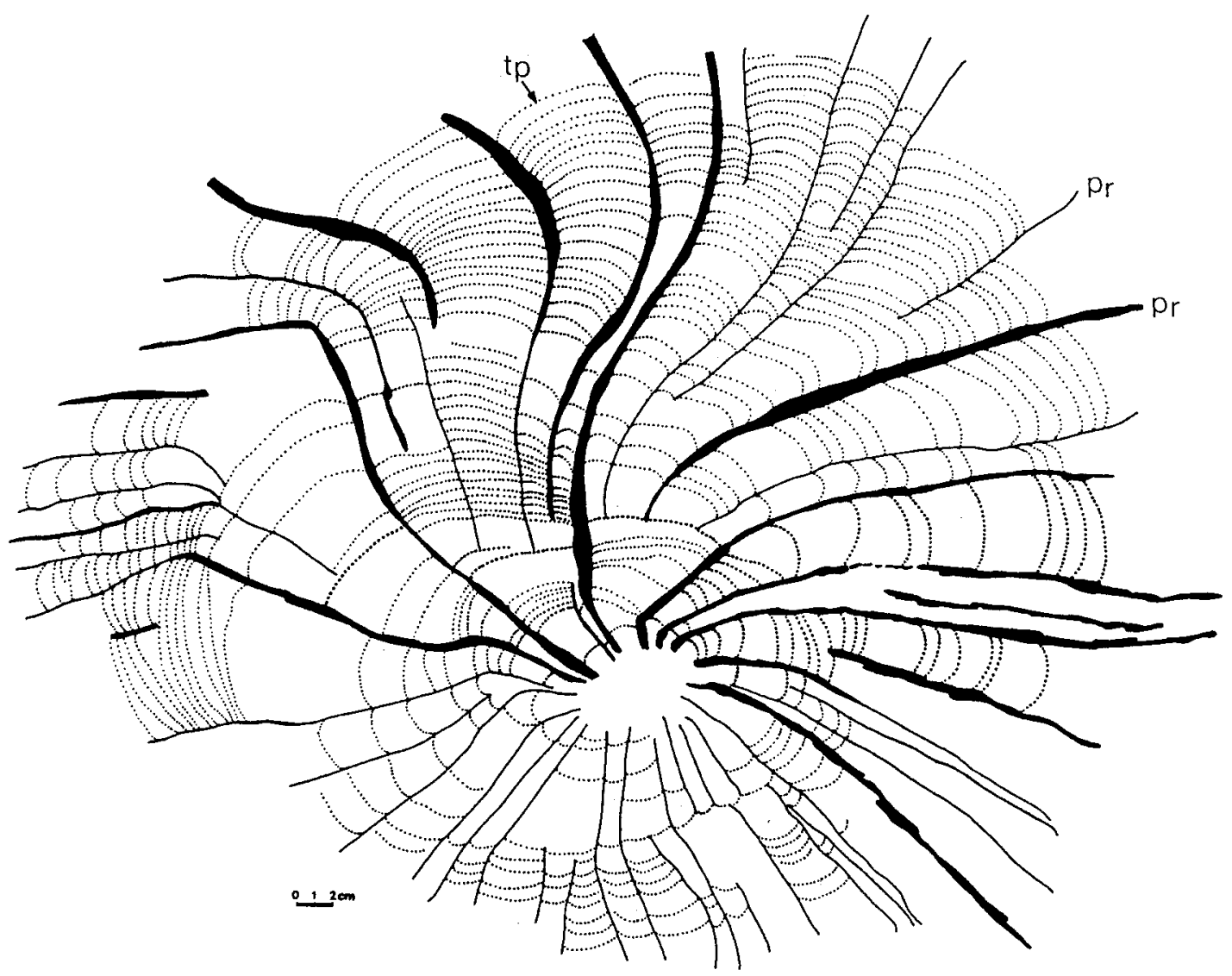

Fig. 4. Rhexoxylon brunoi Artabe, Brea et Zamuner, sp. nov. Diagram of the peripheral zone of centrifugal secondary xylem divided into wedges by parenchymatous rays ( $p r)$ and tangential dilatation parenchyma $(t p)$.

pitting and crossfields with 1 or 2 simple, elliptical slanted pits. The cortex is generally parenchymatous with idioblasts and sometimes with sclerotic nests and vascular strands. A distinctive cork layer has only been described in Rhexoxylon $\mathrm{sp}$. and $R$. brunoi (Petriella, 1978; Taylor, 1992). The antarctic specimen develops a cork layer that reach a millimetre in thickness whereas in the argentinian material is about $2 \mathrm{~cm}$.

Studies on developmental anatomy carried out by Zamuner (1992) demonstrated that in Rhexoxylon wood secondary structure is produced by the simultaneous action of three cambia: normal, supernumerary and remanent. The normal one, located at the distal ends of perimedullar bundles, produces a differential development of their centrifugal part generating the secondary xylem wedges. The remanent cambium favours the formation of abundant dilatation parenchyma unchaining the fragmentation of centrifugal wedges and perimedullar bundles. Finally, the supernumerary one (located in the parenchymatic zone of the perimedullar bundles and in the parenchymatic inner zone of xylematic wedges), activates the production of inverse xylem, originating bundles and centripetal polyxyly. The capacity for developing inverse xylem appeared sporadically in some Paleozoic Pteridosperms and was established as a character in the Medullosans, persisting during the Mesozoic in Corystosperms and Cycadales. In Cycadales has been cited in stems and seedlings of extant and fossil genera: Macrozamia, Lepidozamia, Encephalartos, Cycas, Bowenia, Lepidozamia, Fascivarioxylon and Worsdellia (Worsdell, 1896, 1906; Jain, 1962; Artabe et al., in press).

Differential activity of the cambia generates the different morpho-structural patterns found in the 
Table 1

Comparison of histological characters of the pith, secondary xylem and cortex of the different species of the genus Rhexoxylon: $R$. africanum Bancroft emend. Walton, 1923; $R$. tetrapteridoides Walton emend. Archangelsky et Brett, 1961; R. piatnitzkyi Archangelsky et Brett, 1961; R. brasiliensis Herbst et Lutz, 1988; R. sp. Lutz et Herbst, 1992; R. sp. Taylor, 1992; and R. brunoi

\begin{tabular}{|c|c|c|c|c|c|c|c|}
\hline & R.africanum & R. tetrapteridoides & R. piatnitzkyi & R. brasiliensis & $R . \mathrm{sp}$. & $R . \mathrm{sp}$. & R. brunoi \\
\hline \multicolumn{8}{|l|}{ Pith } \\
\hline Sclerotic nets & $x$ & $x$ & & $x$ & & $?$ & \\
\hline Vascular strands & $\times$ & $x$ & $x$ & & $x$ & $?$ & \\
\hline Idioblasts & & & $x$ & & & $?$ & $x$ \\
\hline Secretory cavities & $\times$ & $\times$ & $\times$ & $\times$ & $\times$ & $?$ & $?$ \\
\hline \multicolumn{8}{|l|}{ Secondary xylem } \\
\hline Radial pitting & $\begin{array}{l}1-3 \text { seriate } \\
\text { alternate }\end{array}$ & $\begin{array}{l}1-3 \text { seriate } \\
\text { alternate }\end{array}$ & $\begin{array}{l}1-2 \text { seriate } \\
\text { alternate }\end{array}$ & 2 seriate? & 1 seriate & $\begin{array}{l}1-2 \text { seriate } \\
\text { alternate }\end{array}$ & $\begin{array}{r}1-2 \text { seriate } \\
\text { opposite }\end{array}$ \\
\hline Cross field pits & $\begin{array}{r}\text { 1-3 circular } \\
\text { elliptical }\end{array}$ & 1 circular & $\begin{array}{r}\text { 1-3 circular } \\
\text { elliptical }\end{array}$ & $?$ & $?$ & $\begin{array}{r}2-4 \text { circular } \\
\text { elliptical }\end{array}$ & $\begin{array}{r}1-2 \text { oblique } \\
\text { lenticular }\end{array}$ \\
\hline Ray width & 1 seriate & 1 seriate & 1 seriate & $?$ & $?$ & $1-2$ seriate & $?$ \\
\hline \multicolumn{8}{|l|}{ Cortex } \\
\hline Only parenchymatic & & & & & $x$ & & \\
\hline Sclerotic nets & $?$ & $x$ & & & & & \\
\hline Vascular strands & $?$ & $x$ & $x$ & & & & \\
\hline Idioblasts & $?$ & & $x$ & & & & \\
\hline Cork layer & $?$ & & $x$ & & & $x$ & $x$ \\
\hline
\end{tabular}

species of Rhexoxylon. Thus, supernumerary cambial activity is scarce in $R$. tetrapteridoides, $R$. piatnitzkyi and Rhexoxylon sp. (Lutz and Herbst, 1992), moderate in $R$. brasiliensis and $R$. brunoi, and abun-

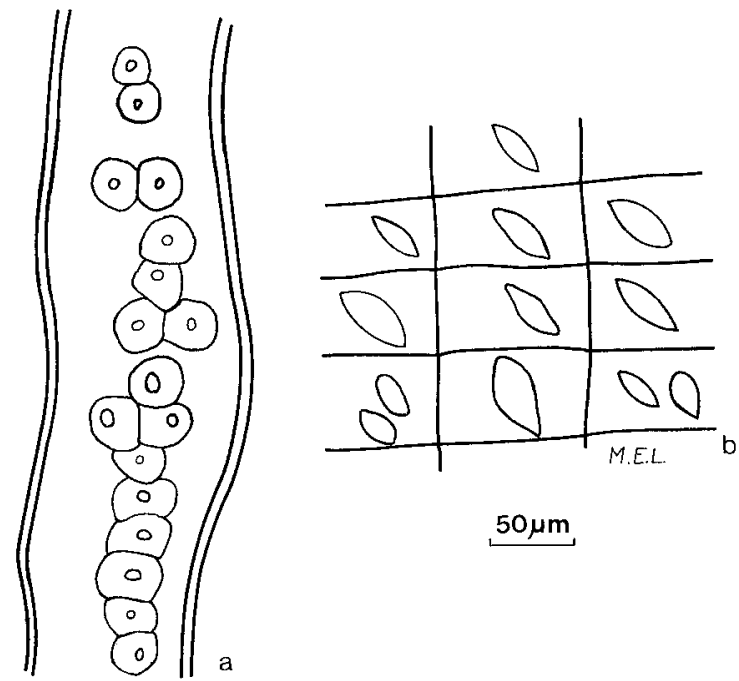

Fig. 5. Rhexoxylon brunoi Artabe, Brea et Zamuner, sp. nov. (a) Tracheid showing uni- or partially biseriate opposite bordered radial pitting. (b) Crossfields with 1 or 2 simple, elliptical slanted pits. dant in $R$. africanum producing up to three cycles of perimedullar bundles. Remanent cambial action is scarce in $R$. tetrapteridoides, $R$. sp. (Lutz and Herbst, 1992) and $R$. brunoi, moderate in $R$. piatnitzkyi, R. brasiliensis and Rhexoxylon sp. (Taylor, 1992), and quite abundant in $R$. africanum. Finally, cambium activity produces scarce radial and tangential parenchyma in $R$. tetrapteridoides, $R$. piatnitzkyi, Rhexoxylon sp. (Lutz and Herbst, 1992) and $R$. brunoi, and abundant parenchyma in $R$. africanum and $R$. brasiliensis.

In mature stems, differential action of the cambia, added to the pith, perimedullary bundles and peripheral xylem wedges diameters, determines the different degrees of manoxyly/picnoxyly characteristic of each species (Table 2). Thus, $R$. africanum would represent the most manoxylic form within the group, with high activity of supernumerary and remanent cambia, abundant radial and tangential parenchyma in xylematic wedges and wide pith. Rhexoxylon tetrapteridoides and $R$. brunoi are the most picnoxylic forms. The first, with scarce supernumerary and remanent cambial activity, scarce radial and tangential parenchyma and small pith; the second, with moderate supernumerary cambial activity, scarce development of remanent cambia, high 


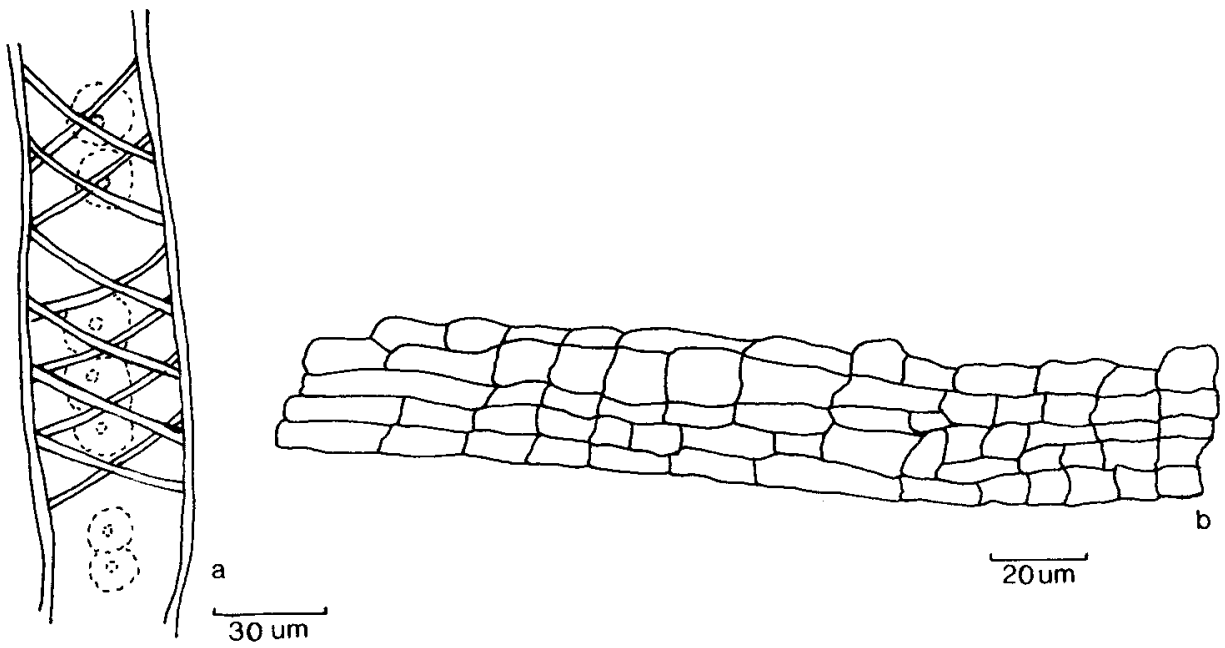

Fig. 6. Rhexoxylon brunoi Artabe, Brea et Zamuner, sp. nov. (a) Tracheid showing the double spiral tertiary thickenings. (b) cork layer.

activity of normal cambium with highly developed wedges with scarce radial and tangential parenchyma and a small pith.

The remaining stem genera assigned to the corystosperms, Antarcticoxylon Seward, 1914, Kykloxylon Meyer-Berthaud et al., 1993 and one stem (stem A) recently described (Brea, 1995), are characterized by a vascular organization different from that of Rhexoxylon. Stem A presents a normal development of primary xylem, with endarch protoxylem. The absence of double perimedullar bundles with centripetal-centrifugal xylem, implies the lack of development of inverse xylem. The distribution of secondary xylem is ordered according to four cycles of wedges separated by circular bands of tangential dilatation parenchyma. Contiguous wedges in each cycle are separated by the development of secondary parenchymatous rays. In this case, the activity of remanent cambium is restricted to tangential dilatation parenchyma separating the cycles of wedges and to that developing within them. A regular morpho-structural pattern thus originates, unlike what happens in Rhexoxylon. Antarcticoxylon is based only on one specimen and one species alone, $A$.

Table 2

Relation between pith, perimedullary strands, secondary xylem and amount of parenchyma of the different species of the genus Rhexoxylon: $R$. africanum Bancroft emend. Walton, 1923; R. tetrapteridoides Walton emend. Archangelsky et Brett, 1961; R. piatnitzkyi Archangelsky et Brett, 1961; R. brasiliensis Herbst et Lutz, 1988; $R$. sp. Lutz et Herbst, 1992; R. sp. Taylor, 1992; and R. brunoi

\begin{tabular}{|c|c|c|c|c|c|c|c|c|}
\hline & \multicolumn{3}{|c|}{ Diameter } & \multirow{2}{*}{$\begin{array}{l}\text { Ring of } \\
\text { perimedullary } \\
\text { strands }\end{array}$} & \multirow{2}{*}{$\begin{array}{l}\text { Wedges of } \\
\text { secondary } \\
\text { xylem }(\mathrm{cm})\end{array}$} & \multirow{2}{*}{$\begin{array}{l}\text { Amount of } \\
\text { parenchyma }\end{array}$} & \multicolumn{2}{|c|}{ Cambium activity } \\
\hline & $\begin{array}{l}\text { Total } \\
(\mathrm{cm})\end{array}$ & $\begin{array}{l}\text { Pith } \\
(\mathrm{cm})\end{array}$ & $\begin{array}{l}\text { Pith }+ \text { perimedullary } \\
\text { strands }(\mathrm{cm})\end{array}$ & & & & remanent & supernumerary \\
\hline R. africanum & 50 & 6 & 24 & $\begin{array}{l}1 \text { or } 2 \text { complete } \\
1 \text { incomplete }\end{array}$ & 14 & abundant & great & great \\
\hline R. tetrapteridoides & 18 & 2 & 6.6 & 1 complete & 5.5 & scarce & scarce & scarce \\
\hline R. piatnitzkyi & 100 & 6.5 & 12 & 1 complete & 25 & scarce & moderate & scarce \\
\hline R. brasiliensis & 43 & $7 \times 5$ & 16 & $\begin{array}{l}1 \text { complete } \\
1 \text { incomplete }\end{array}$ & 14 & abundant & moderate & moderate \\
\hline$R . \mathrm{sp}$. & 60 & $3.2 \times 1.3$ & 5.3 & 1 incomplete & 6 & scarce & scarce & scarce \\
\hline$R . \mathrm{sp}$. & 35 & $?$ & $?$ & $?$ & $?$ & $?$ & moderate & $?$ \\
\hline R. brunoi & 76 & $2.4 \times 1.7$ & 6.6 & $\begin{array}{l}1 \text { complete } \\
1 \text { incomplete }\end{array}$ & 38 & scarce & scarce & moderate \\
\hline
\end{tabular}


priestleyi, possibly of Permian age of Antarctica (Seward, 1914; Meyer-Berthaud and Taylor, 1991). According to Archangelsky and Brett (1961) Antarcticoxylon has a small diameter, scarcely divided vascular cylinder, endarch protoxylem, and shows no evidence of cambial activity at the perimedullar region. Finally, Kykloxylon has been found associated to leaves assigned to Dicroidium fremouwensis Pigg, 1990 (Meyer-Berthaud et al., 1992, 1993). This species consists of stems up to $2 \mathrm{~cm}$ in diameter with endarch primary xylem and normal undivided secondary xylem.

Corystospermic woods show an organization of primary and secondary tissues determined by typical and atypical cambial activity.

\section{References}

Archangelsky, S., 1968. Studies on Triassic fossil plants from Argentina. IV. The leaf genus Dicroidium and its possible relation to Rhexoxylon stems. Palaeontology 11 (4), 500-512.

Archangelsky, S., Brett, D.W., 1961. Studies on Triassic fossil plants from Argentina. I. Rhexoxylon from the Ischigualasto Formation. Philos. Trans. R. Soc. London B 706 (244), 1-19.

Artabe, A.E., Zamuner, A.B., Stevenson, D. Wn., in press. Two new petrified Cycad stems, Brunoa gen. nov. and Worsdellia gen nov., from the Cretaceous of the Bajo de Santa Rosa, province of Río Negro, Argentina. Botanical Review.

Artabe, A.E., Brea, M., Zamuner, A., 1994. Una nueva especie de Rhexoxylon Bancroft emend. Archangelsky y Brett 1961 del Triásico de Paramillo de Uspallata, Mendoza, Argentina. IX Simp. Argentino de Paleobotánica y Palinología, Mar Del Plata, 1994, p. 36.

Bancroft, N., 1913. Rhexoxylon africanum, a new Medullosean stem. Trans. Linn. Soc. London Ser. 2 (Bot.) 8, 87-103.

Bonnamain, S., Boureau, E., Ellenberg, P., 1963. Sur une nouvel echantillon de Rhexoxylon africanum Bancroft des couches du Molteno du Basutoland. C. R. Somm. Seances Soc. Geol. Fr. 8, 275-276.

Brea, M., 1995. Estudio de la Paleoflora de la secuencia triásica de Agua de la Zorra, provincia de Mendoza. Thesis, Univ. Nacional de La Plata, 202 pp. (unpubl.).

Brett, D.W., 1968. Studies on Triassic fossil plants from Argentina. III. The trunk of Rhexoxylon. Palaeontology 11 (2), 236-245.

Conwentz, H., 1885. Arboles fósiles del Río Negro. Bol. Ac. Cienc. Córdoba 5 (7), 435-456.

Darwin, C., 1846. Geological observations on South America. Being the third part of the Geology of the voyage of the Beagle, during the years 1832 to 1836. Smith, Elder and Co., London, 279 pp.

Du Toit, A.L., 1927. The fossil flora of the Upper Karroo Beds. Part II. Ann. S. Afr. Mus. 22 (2), 289-420.
Groeber, P., 1939. Mapa geológico de Mendoza. Physis 14, 171220.

Harrington, H.J., 1971. Descripción geológica de la hoja 22c, 'Ramblón' provincias de Mendoza y San Juan. Minist. Ind. Min. Subsecr. Miner. Bol. 114, 1-87.

Herbst, R., Lutz, A., 1988. Rhexoxylon brasiliensis n.sp. (Corystospermaceae, Pteridospermales) from the Upper Triassic Caturrita Formation, Brazil, with comments on biology and environment. Meded. Rijks Geol. Dienst 42, 21-28.

Jain, K.P., 1962. Fascivarioxylon mehtae gen. et sp. nov., a new petrified cycadean wood from the Rajmahal Hills, Bihar, India. Palaeobotanist 11, 138-143.

Kokogian, D.A., Mancilla, D.H., 1989. Análisis estratigráfico secuencial de la Cuenca Cuyana. In: Chebli, G., Spalletti, L. (Eds.), Cuencas Sedimentarias Argentinas. (Serie Correlación Geológica, 6). Univ. Nac. Tucumán, pp. 169-201.

Kokogian, D.A., Fernández Seveso, F., Mosquera, A., 1993. Las secuencias sedimentarias triásicas. In: Ramos, V. (Ed.), Relatorio Geología y Recursos Naturales de Mendoza. Asociación Geológica Argentina, I (7), 65-78.

Kräusel, R., 1956. Lianen aus den Karru-Schichten Sud-Afrikas. Senckenbergiana Lethaea 37 (1-2), 1-16.

Kurtz, F., 1921. Atlas de plantas fósiles de la República Argentina. Actas Acad. Nac. Cienc. Córdoba 7 (3), 129-153.

Linares, E., Gonzáles, R., 1990. Catálogo de edades radimétricas de la República Argentina 1957-1987. Asoc. Geol. Argent. Ser. B (Didáct. Complement.) 19, 1-628.

Lutz, A., Herbst, R., 1992. Una nueva especie de Rhexoxylon del Triásico de Barreal, San Juan, Argentina. Actas VIII Simp. Argentino de Paleobotánica y Palinología, Buenos Aires. Asoc. Paleontol. Argent. Publ. Espec. 2, 73-76.

Massabie, A.C., 1985. Filón capa Paramillo de Uspallata, su caracterización geológica y edad, Paramillo de Uspallata, Mendoza. Primeras Jornadas sobre Geología de Precordillera, San Juan, Actas I, 325-330

Massabie, A.C., Rapalini, A.E., Soto, J.L., 1985. Estratigrafía del Cerro Los Colorados, Paramillo de Uspallata, Mendoza. Primeras Jornadas sobre Geología de Precordillera, San Juan, Actas I, 71-76.

Meyer-Berthaud, B., Taylor, T.N., 1991. A probable conifer with podocarpacean affinities from the Triassic of Antarctica. Rev. Palaeobot. Palynol. 67, 179-198.

Meyer-Berthaud, B., Taylor, E.L., Taylor, T.N., 1992. Reconstructing the Gondwana seed fern Dicroidium: evidence from the Triassic of Antarctica. Geobios 25 (3), 341-344.

Meyer-Berthaud, B., Taylor, T.N., Taylor, E.L., 1993. Petrified stems bearing Dicroidium leaves from the Triassic of Antarctica. Palaeontology 36 (2), 337-356.

Obaton, M., 1960. Les lianes ligneuses a structure anormale des forest denses D'Afrique occidentale. Ann. Sci. Nat. 12e Ser. (Bot. Biol. Veg.) 1 (1), 1-220.

Petriella, B., 1978. La reconstrucción de Dicroidium (Pteridospermopsida, Corystospermaceae). Obra Centen. Mus. La Plata 5, 107-110.

Pigg, K.B., 1990. Anatomically preserved Dicroidium foliage from the central Transantarctic Mountains. Rev. Palaeobot. Palynol. 66, 129-145. 
Ramos, V.A., 1993. El magmatismo Triásico-Jurásico de intraplaca. XII Congr. Geológico Argentino y II Congr. de Exploración de Hidrocarburos. In: Ramos, V. (Ed.), Relatorio Geología y Recursos Naturales de Mendoza I (8), 79-86.

Ramos, V.A., Kay, S.M., 1991. Triassic rifting and associated basalts in the Cuyo Basin, central Argentina. In: Harmon, R.S., Rapela, C.W. (Eds.) Andean Magmatism and its Tectonic Setting. Geol. Soc. Am. Spec. Pap. 265, 79-91.

Seward, A.C., 1914. Antarctic fossil plants. Br. Mus. (Nat. Hist.) Br. Antarct. (Terra nova) Exped. (Geol.) 1, 1-49.

Stappenbeck, R., 1910. La Precordillera de San Juan y Mendoza. An. Minist. Agric. Sec. Geol. Mineral. Miner. 4 (3), 3-183.

Stipanicic, P.N., 1979. El Triásico del Valle del Río Los Patos, Provincia de San Juan. In: Turner, J.C.M. (Ed.), Geología Regional de la República Argentina, I. Acad. Nac. Cienc. Córdoba, pp. 695-744.

Stipanicic, P.N., Herbst, R., Bonetti, M.I.R., 1996. Floras Triásicas. Ac. Nac. Cienc. Córdoba 11, 127-184.

Strelkov, E.E., Alvarez, L.A., 1984. Análisis estratigráfico y evolutivo de la cuenca triásica mendocina-sanjuanina. IX Congr. Geológico Argentino, Actas 3, 115-130.
Taylor, E.L., 1992. The occurrence of a Rhexoxylon-like stem in Antarctica. Cour. Forschungsinst. Senckenberg 147, 183-198. Thomas, H.H., 1933. On some Pteridospermous plants from the Mesozoic rocks of South Africa. Philos. Trans. R. Soc. London B 222, 193-254.

Walton, J., 1923. On Rhexoxylon Bancroft, a Triassic genus of plants exhibiting a liane-type of vascular organization. Philos. Trans. R. Soc. London B 212, 79-109.

Windhausen, H., 1941. El 'Rético' de Paramillo de Uspallata (Mendoza). Thesis, Univ. Nac. de La Plata, No. 28, 72 pp. (unpubl.).

Worsdell, W.C., 1896. The anatomy of the stem of Macrozamia compared with that of other genera of Cycadaceae. Ann. Bot. 10 (11), 601-620.

Worsdell, W.C., 1906. The structure and origin of the Cycadaceae. Ann. Bot. 20 (78), 129-155.

Zamuner, A.B., 1992. Estudio de una tafoflora de la localidad tipo, de la Formación Ischigualasto (Neotrias), Provincia de San Juan. Thesis, Univ. Nac. La Plata, No. 583, 97 pp. (unpubl.). 